\title{
ТЕОРЕТИЧНА МОДЕЛЬ ТВОРЧОЇ ОСОБИСТОСТІ МАЙБУТНЬОГО РЕЖИСЕРА-ПЕДАГОГА
}

\author{
Ніна Гусакова ${ }^{1 \mathrm{a}}$, Валерія Штефюк ${ }^{2 \mathrm{a}}$ \\ ${ }^{1}$ кандидат педагогічних наук, доцент; e-mail: gusakova_nina@ukr.net; ORCID: 0000-0003-0185-4780 \\ ${ }^{2}$ магістр; e-mail: 14valeri777@gmail.com; ORCID: 0000-0002-0981-3003 \\ а Київський національний університет культури і мистецтв, Київ, Україна
}

\begin{abstract}
Анотація
Метою роботи є виявлення новітніх підходів до створення моделі творчої особисті режисерапедагога, її структури, визначення розвитку індивідуальної обдарованості. Методологічною базою $є$ використання аналітичного, функціонального, порівняльного, мистецтвознавчого, культурологічного, системного, аксіоматичного методів дослідження основних складових формування особистості майбутнього режисера-педагога, виходячи з концептуальних положень педагогічної творчості про те, що формування моделі майбутнього фахівця виступає як об'єктивний творчий процес. Наукова новизна полягає у розробленні концепції про основні складові моделі творчої особистості, яка містить синтез теорії та практики, знання, уміння, активність, взаємодію, продуктивність, взаємозалежність і взаємозбагачення режисерської та педагогічної професійної творчості. Висновки. У результаті здійсненого дослідження можемо підсумувати. По-перше, до загальної структури моделі творчої особистості майбутнього режисера-педагога належать такі підрозділи: спрямованість особистості; індивідуальна культура (досвід); ії характерологічні властивості та якості; самотворчість особистості; по-друге, теоретична модель творчої особистості майбутнього режисера-педагога є регулятором процесу його художньо-творчого та педагогічного становлення в підготовці до соціально-культурної діяльності; по-третє, запропонована модель визначає напрями практичної роботи розвитку режисера-педагога.
\end{abstract}

Ключові слова: режисер-педагог; театр; модель творчої особистості

\section{Постановка проблеми}

Питання розвитку творчої особистості набуває потреби дослідження як процесу, так і результату входження її в соціально-культурний простір. Такий процес охоплює сформованість та вдосконалення творчих потреб і можливостей, управління емоційно-вольовою сферою, організацію власної інтелектуальнотворчої діяльності й оцінку та самооцінку дій, засвоєння моральних цінностей і розвиток мотиваційного процесу спрямованості особистості. Оцінка та самооцінка діяльності особистості з'являється в процесі усвідомлення себе в професії, що набуває певної потреби у вирішенні питання формування діяльнісної моделі творчої особистості майбутнього режисера-педагога та його відносин як фахівця з соціокультурною сферою, процесом сьогодення.

Гуманістичний підхід у педагогічній науці орієнтує на розвиток особистості, на її цінності, особистісну свободу, на самотворчість у всіх сферах діяльності. 
Гуманізація освіти - це максимально продуктивна підготовка особи з акцентуалізацією на творчість.

3 погляду гуманістичної парадигми як філософської основи гуманістичного підходу в освіті висунуто ряд ідей: провідне положення «гуманістичного» розуму з його настановами на пріоритетний розвиток особистості; уявлення особистості як принципово складної, змістовної, неординарної сутності; орієнтація на демократичний стиль у діяльності, управлінні, характері суб'єкт-суб'єктних відносин; максимальне самовираження особистості на підставі розуміння своєї сутності; вивчення творчих можливостей, створення особистісного образу «я», що впливає на формування цілісної «Я-концепції» (Маслоу, 1997; Роджерс, 1994).

Керуючись концептуальними положеннями педагогіки, спираючись на сучасну науку про творчість і виходячи із завдань дослідження, ми визначили мету розробити та здійснити теоретико-методологічне обґрунтування моделі творчої особистості майбутнього режисера-педагога.

\section{Аналіз досліджень і публікацій}

У науковій літературі є різні підходи до обумовлення розвитку особистості. Аналіз наукового матеріалу дає можливість виявити різні напрями дослідження проблем формування та розвитку особистості. Науковці (Л. І. Божович (1995), О. М. Леонтьєв (1977), С. Л. Рубінштейн (1957), С. О. Сисоєва (1997)) підтверджують думки про те, що саме соціальні умови формують цей процес.

В. О. Моляко (1991) підкреслює, що творча діяльність $є$ одним із чинників визначення людської сутності, а здатність до творчості визначає особистість як творчу. Природу творчості, яка спрямована на перетворюючу діяльність, саморозвиток та самореалізацію, досліджує Л.Н.Коган (1981).

Творчість як діяльність для створення нового, що є в самій природі людини, аналізують психологи: Л. С. Виготський (1987), В. О. Моляко (1991), В. В. Рибалка (1996).

Метою роботи є виявлення новітніх підходів до створення моделі творчої особистості режисера-педагога, її структури, визначення розвитку індивідуальної обдарованості.

\section{Виклад основного матеріалу}

В. О. Моляко зазначає, що талант, обдарованість породжують здатність до художньо-творчої діяльності, але творча діяльність не зводиться до однієї унікальності її продуктів, вона має містити в собі певну суспільну вагомість. Визначаючи творчість як результат створення нового, автор розглядає їі і як репродуктивну, тобто відтворюючу діяльність (1991).

В. О. Лісовська доводить, що дослідження проблеми висвітлює інші підходи до визначення природи «творчості», а саме з позицій глибокого вивчення внутрішніх особливостей певного виду творчої діяльності. При цьому необхідно провести грань між художньою творчістю та іншими видами діяльності (1984). 
Поняття «творчість» як процес людської діяльності з філософського погляду визначається як уявна та практична діяльність, у результаті якої створюються оригінальні, неповторні цінності, встановлюються нові закономірності, факти, властивості, а також сприймання духовної культури.

Педагогічна творча діяльність має науково-дослідний характер, в якому проявляється індивідуальний творчий пошук, що ґрунтується на усвідомленні інновацій, досягненнях у системі сучасної науки, культури, у визначенні оптимальних умов ефективності здійснення особистісної програми креативності педагогічного пошуку, прогнозуванні результативності творчо-педагогічної діяльності та інше.

Як творче виконання викладачем професійних функцій на рівні мистецтва педагогічну майстерність досліджували такі науковці, як-от І. А. Зязюн, О. Г. Мороз і В. Л. Омеляненко. Автори підкреслюють, що майстерність педагога формується й удосконалюється на підставі творчої активності, науково-перетворюючої діяльності. Високий рівень майстерності досягається внаслідок педагогічної творчості за рахунок сумлінності, активності, працелюбства, подолання труднощів, перетворення умінь у навички, тобто після накопичення досвіду за певний час (Мороз та Омеляненко, 1992).

С. О. Сисоєва розглядає педагогічну творчість викладача як особистісноорієнтовану розвиваючу взаємодію суб'єктів навчально-виховного процесу, зумовлену специфікою психолого-педагогічних відносин між ними та спрямовану на формування творчої особистості тих, хто навчається, і підвищення рівня його творчої педагогічної діяльності (1997).

На думку автора, педагогічній творчості притаманні вирішення суперечностей проблемних ситуацій, наявність об'єктивних (соціальних, матеріальних) та суб'єктивних (знання, уміння, професійні навички, характерні особливості, мотивація, творчі уміння) умов для творчості; об'єктивна чи суб'єктивна новизна й оригінальність процесу та результату; соціальна й особиста важливість і прогресивність; взаємообумовленість впливу на розвиток викладача та студента зовнішніх факторів і внутрішнього саморозвинення особистості (самовиховання, саморозвиток), а також співтворчий характер суб'єктів педагогічного процесу (Сисоєва, 1997).

Водночас процес становлення творчої особистості має свої специфічні закономірності. При цьому загальносоціальний, конкретно-соціальний та індивідуально-соціальний аспекти, які впливають на їі формування, перебувають у діалектичній єдності та виступають як загальне, особливе й одиничне.

Дослідники (В.І.Завязинський (1987), В.В.Рибалка (1996)) зазначають, що творча особистість є завжди своєрідною та неповторною, складною та багатовимірною; вона є прикладом яскравої індивідуальності з властивими саме їй протиріччями та досягненнями, якій притаманна величезна інтелектуальна та творча напруженість розумової, духовної праці.

Творча особистість майбутнього режисера-педагога - це суб'єкт творчих соціальних відносин і свідомої творчої діяльності в соціокультурному просторі.

Досліджуючи питання теоретичної моделі творчої особистості режисерапедагога, було виявлено напрями їі спрямованості, а саме психолого-педагогічний 
та діяльнісний, що зумовлені розвитком естетичних переваг особистості в суспільному житті та мистецтві. Особистісна спрямованість як елемент свідомості, світосприйняття виявляється майже в усіх аспектах життєдіяльності особи. Від того, наскільки особистість спроможна реалізувати досягнення суспільної практики, проявляти в ній свої індивідуальні можливості та перетворювати у внутрішню потребу творчу діяльність, залежить соціальне значення окремої особи.

Спрямованість особистості також визначається розвитком її мотиваційної сфери. Мотиваційні формування спонукають до діяльності щодо реалізації потреб, інтересів, смаків, виступаючи домінантою спрямованості особистості до уявлення про «ідеальний стан», що обумовлено визнаною системою цінностей «реального стану».

Отож, компонентами складової підструктури спрямованості особистості $€$ гуманістична спрямованість; соціокультурна спрямованість у різних її проявах; орієнтаційно-мотиваційна сфера.

Особливості інтеріоризації соціального досвіду накопичення наукових, спеціальних знань, засвоєння стійкої демократичної стратегії поведінки зумовлюють успішність творчої діяльності особистості. Л.Н.Коган підкреслює, що специфічні культурні орієнтації, норми, традиції конкретного культурного середовища, в якому безпосередньо перебуває особистість, визначають інтегральне поняття «культурний досвід» з «актуальної культури» - як суспільно необхідний мінімум вимог до культурного рівня особистості та досвід зі «спеціальної культури» - професійної діяльності. Культурна діяльність виступає як «самореалізація - результат і критерій її розвитку, а сама особистість - як суб'єкт культурної творчості. Через процес оволодіння культурою можливим стає виховний вплив на сутність особистості - на «ядро» особистості» (1981).

Провідною, об'єктивно заданою тенденцією розвитку особистості є розширення їі стосунків, поява нових можливостей діяльності. Сфера потенційного виконує важливу детермінуючу функцію розвитку особистості.

Досвід театрально-педагогічної діяльності - дуже важлива якість майбутнього режисера-педагога, що відображає рівень оволодіння цією діяльністю, банком сформованості інтегративних психолого-педагогічних та спеціальних знань, проявом умінь, оперуванням прийомами самодетермінації та самореалізації в професійно-педагогічному саморозвитку.

Виявлення психологічної діяльності особистості здійснюється завдяки активізації почуттів, мислення, спонукальних дій, прояву волі. Якщо в процесі сприйняття, мислення й уявлення відображаються різноманітні предмети та явища, їх різні якості та властивості, всебічні зв'язки та залежності, то в емоціях і почуттях людина проявляє своє ставлення до змісту того, що вона пізнає. Емоції та почуття - це своєрідне особистісне ставлення людини до навколишнього світу та до самого себе (Беспалько, 1972).

Світ почуттів й емоцій складний і різноманітний. Сама особистість не завжди усвідомлює витонченість його організації та багатогранність вираження. Складність аналізу пережитих почуттів пояснюється також і тим, що ставлення до предметів 
і явищ залежить від тієї пізнавальної діяльності або вольової активності, яку виявляє особистість.

У діяльності актора-митця К. С. Станіславський відзначав актуальність використання широкого спектра емоційно-вольового потенціалу. Такі театральні діячі «виділяються з-поміж усіх у спектаклі особливою ритмічною гармонією всієї ролі, вивільненням фізичних і психічних дій; вони пробиваються крізь перешкоди всіх умовностей сцени, зменшують відстань між глядацьким залом і собою та влучають прямо в серце людей, ведуть їх за собою в життя цієї своєї творчої хвилини лише тому, що вони осягли природу зображуваних ними пристрастей і вивели з них дією своєї геніальної інтуїції цінності слова, яке й кинули глядачеві в правдивій і правильній фізичній дії» (Беспалько, 1972).

У театральному мистецтві естетичне ставлення, естетичне переживання, що проявляється в художньому творі, стає особистим переживанням і ставленням режисера - актора - глядача завдяки особливому механізму взаємодії суб'єктів, які сприймають об'єкт - мистецький твір, втілений у художньо-творчий процес театральної постановки.

Воля як усвідомлене регулювання особистістю своїх дій і вчинків, що потребують переборення внутрішніх і зовнішніх труднощів, проявляється в різних аспектах функціонування пізнавальної, емоційної, практичної та специфічної художньотворчої діяльності. Вольові дії супроводжують процес усвідомлення фахівцем мети режисерської концепції, планування роботи над виставою, реалізацію творчих задумів. Планування постановки вистави відповідає меті та охоплює складні вольові дії режисера: напруження та витрачання значної енергії внутрішніх сил у проектуванні структури здійснення задуму; в окресленні вимог до суб'єктів взаємодії; у визначенні шляхів, умов і засобів виконання режисерської концепції, що здійснюється в постійному зіставленні з «еталонним» показником; у координації контролюючих і корегуючих вольових зусиль, що мають місце у створенні фахівцем вистави. Настанова на «максимальну віддачу» викликає сконцентрованість вольових зусиль у створенні «атмосфери» вистави, що й виявляє сформованість творчих можливостей, творчих емоційно-вольових потенцій режисера для забезпечення ефективності художньо-творчої та педагогічної діяльності.

Наукова новизна полягає у розробленні концепції про основні складові моделі творчої особистості, яка охоплює синтез теорії та практики, знання, уміння, активність, взаємодію, продуктивність, взаємозалежність і взаємозбагачення режисерської та педагогічної професійної творчості.

\section{Висновки}

У театральному мистецтві естетичне ставлення, естетичне переживання, що проявляється в художньому творі, стає особистим переживанням і ставленням режисера - актора - глядача завдяки особливому механізму взаємодії суб'єктів, які сприймають об'єкт - мистецький твір, втілений у художньо-творчий процес театральної постановки. Загальна структура моделі творчої особистості майбутнього режисера-педагога складається із спрямованості особистості; 
індивідуальної культури (досвіду); ії характерологічних властивостей та якостей; самотворчості особистості. Теоретична модель творчої особистості майбутнього режисера-педагога $є$ регулятором процесу його художньо-творчого та педагогічного становлення в підготовці до соціально-культурної діяльності.

\section{СПИСОК ПОСИЛАНЬ}

Беспалько, В.П., 1972. Некоторые вопросы педагогики высшего образования. Рига.

Божович, Л.И., 1995. Проблемы формирования личности. В: Д.И. Фельдштейна, ред. Избранные психологические труды. Москва: Воронеж.

Выготский, Л.С., 1987. Психология искусства. Москва: Педагогика.

Доній, В.М. ред., 1997. Мистецтво життєтворчості особистості. Ч.1: Теорія і технологія життєтворчості. Київ: Інститут засобів та методів навчання.

Загвязинский, В.И., 1987. Педагогическое творчество учителя. Москва: Педагогика.

Коган, Л.Н., 1981. Всестороннее развитие личности и культура. Москва: Знание.

Леонтьев, А.Н., 1977. Деятельность. Сознание. Личность. Москва: Политиздат.

Лисовская, В.О., 1984. Роль и место творческого компонента в профессиональнопедагогической структуре личности воспитателя. Киев: Коллектив и личность, с.29-35.

Маслоу, А., 1997. Психология бытия. Москва: Рефл.-бук,

Моляко, В.А., 1991. Творческая одаренность и воспитание творческой личности. Киев: Знание

Мороз, О.Г. та Омеляненко, В.Л., 1992. Перші кроки до майстерності. Київ: Знання.

Рибалка, В.В., 1996. Психологія розвитку творчої особистості. Київ: Інститут засобів та методів навчання.

Роджерс Карл Р., 1994. Взгляд на психотерапию. Становление человека. Москва: Прогресс. Рубинштейн, С.Л., 1957. Бытие и сознание. О месте психического во всеобщей взаимосвязи явлений материального мира. Москва: АН СССР.

Сисоєва, С.О., 1997. Теоретичні і методичні основи підготовки вчителя до формування творчої особистості учня : автореф. дис. ... д-ра наук. Інститут педагогіки і психології професійної освіти. Київ.

\section{REFERENCES}

Bespalko, V.P., 1972. Nekotorye voprosy pedagogiki vysshego obrazovaniya [Some issues of pedagogy of higher education.]. Riga.

Bozhovich, L.I., 1995. Problemy formirovaniya lichnosti. [Problems of personality formation]. In: D.I. Feldshtejna, ed. Izbrannye psikhologicheskie trudy. Moscow: Voronezh.

Donii, V.M. ed., 1997. Mystetstvo zhyttietvorchosti osobystosti. Ch.1: Teoriia i tekhnolohiia zhyttietvorchosti [Art life life. Part 1: Theory and technology of living]. Kyiv: Instytut zasobiv ta metodiv navchannia.

Kogan, L.N., 1981. Vsestoronnee razvitie lichnosti $i$ kultura [Comprehensive personal development and culture]. Moscow: Znanie.

Leontev, A.N., 1977. Deyatelnost. Soznanie. Lichnost [Activity. Consciousness. Personality]. Moscow: Politizdat.

Lisovskaya, V.O., 1984. Rol i mesto tvorcheskogo komponenta $v$ professionalno-pedagogicheskoj strukture lichnosti vospitatelya [The role and place of the creative component in the professional and pedagogical structure of the teacher's personality.]. Kiev: Kollektiv i lichnost, pp.29-35.

Maslou, A., 1997. Psikhologiya bytiya [Psychology of Being]. Moscow: Refl.-buk,

Molyako, V.A., 1991. Tvorcheskaya odarennost i vospitanie tvorcheskoj lichnosti [Creative talent and upbringing of a creative personality]. Kiev: Znanie

Moroz, O.H. and Omelianenko, V.L., 1992. Pershi kroky do maisternosti [First crocants before the master]. Kyiv: Znannia. 
Rodzhers Karl R., 1994. Vzglyad na psikhoterapiyu. Stanovlenie cheloveka [A look at psychotherapy. The formation of man]. Moscow: Progress.

Rubinshtejn, S.L., 1957. Bytie i soznanie. O meste psikhicheskogo vo vseobshchej vzaimosvyazi yavlenij materialnogo mira [Being and consciousness. About the place of the mental in the universal interrelation of the phenomena of the material world]. Moscow: USSR Academy of Sciences.

Rybalka, V.V., 1996. Psykholohiia rozvytku tvorchoi osobystosti [Psychology of development of creativity]. Kyiv: Instytut zasobiv ta metodiv navchannia.

Sysoieva, S.O., 1997. Teoretychni i metodychni osnovy pidhotovky vchytelia do formuvannia tvorchoi osobystosti uchnia [Theoretical and methodical basis of the preparation of the reader before the formation of creative art]. Extended abstract of Doctor's thesis. Instytut pedahohiky i psykholohii profesiinoi osvity. Kyiv.

Vygotskij, L.S., 1987. Psikhologiya iskusstva [Psychology of art]. Moscow: Pedagogika.

Zagvyazinskij, V.I., 1987. Pedagogicheskoe tvorchestvo uchitelya [Teacher's pedagogical creativity]. Moscow: Pedagogika.

\title{
ТЕОРЕТИЧЕСКАЯ МОДЕЛЬ ТВОРЧЕСКОЙ ЛИЧНОСТИ БУДУЩЕГО РЕЖИССЕРА-ПЕДАГОГА
}

\author{
Нина Гусакова ${ }^{1 \mathrm{a}}$, Валерия Штефюк ${ }^{2 \mathrm{a}}$ \\ ${ }^{1}$ кандидат педагогических наук, доцент; e-mail: gusakova_nina@ukr.net; ORCID: 0000-0003-0185-4780 \\ ${ }^{2}$ магистр; e-mail: 14valeri777@gmail.com; ORCID: 0000-0002-0981-3003 \\ а Киевский национальный университет культуры и искусств, Киев, Украина
}

\section{Аннотация}

Цель работы - выявить новейшие подходы к созданию модели творческой личности режиссера-педагога, ее структуры; определить развитие индивидуальной одаренности. Методология исследования определяется в применении аналитического, функционального, сравнительного, искусствоведческого, культурологического, системного, аксиоматического методов исследования основных составляющих формирования личности будущего режиссерапедагога, исходя из концептуальных положений педагогического творчества о том, что формирование модели будущего специалиста выступает как объективный творческий процесс. Научная новизна заключается в разработке концепции об основных составляющих моделях творческой личности, которая включает в себя синтез теории и практики, знания, умения, активность, взаимодействие, производительность, взаимозависимость и взаимообогащение режиссерским и педагогическим профессиональным творчеством. Выводы. В результате проведенного исследования можно подытожить. Во-первых, общая структура модели личности будущего режиссера-педагога состоит из: направленности личности; индивидуальной культуры (опыта); ее характерологических свойств и качеств; автотворчества личности; во-вторых, теоретическая модель творческой личности будущего режиссера-педагога выступает как регулятор процесса его художественно-творческого и педагогического становления в подготовке к социально-культурной деятельности; в-третьих, предложенная модель определяет направления практической работы в развитии режиссера-педагога.

Ключевые слова: режиссер-педагог; театр; модель творческой личности 


\title{
THE THEORETICAL MODEL OF THE CREATIVE PERSONALITY OF THE FUTURE DIRECTOR-TEACHER
}

\author{
Nina Husakova ${ }^{1 a}$, Valeriia Shtefiuk ${ }^{2 a}$ \\ ${ }^{1} \mathrm{PhD}$ in Pedagogical Sciences, Associate Professor; \\ e-mail: gusakova_nina@ukr.net; ORCID: 0000-0003-0185-4780 \\ ${ }^{2}$ Master; e-mail:14valeri777@gmail.com; ORCID: 0000-0002-0981-3003 \\ ${ }^{a}$ Kyiv National University of Culture and Arts, Kyiv, Ukraine
}

\begin{abstract}
The aim of the work is to identify new approaches to creating a model of creative personal directorteacher, its structure, definition of the development of individual talent. The methodology of the research is to combine the analytical, functional, comparative, cultural, systematic and axiomatic methods for studying the main components of the personality formation of the future directorteacher. The author of this article is guided by the conceptual fundamentals of a pedagogical creativity, in particular, that the formation of the model of a future specialist is proceeded as an objective creative process. Scientific novelty. The development of the concept of the basic components of the model of the creative personality, which includes the synthesis of the theory and practice, knowledge, skills, activity, interaction, productivity, interdependence and mutual enrichment of directing and pedagogical professional creativity. Conclusions. As a result of the research we can sum up. First, to the general structure of the creative personality model of the future director-teacher, there are the following divisions. The model of the creative personality of the future director-teacher includes substructures of it's basic structure, such as the orientation of an individual, individual culture of a person (experience), characterization and personality qualities, self-creativity of personality. The creative personality's theoretical model of the future director-teacher acts is as a regulator of the process of his creative and pedagogical formation in preparation for social and cultural activities. The proposed model defines the directions of practical work in the creative personality development of the future director-teacher.
\end{abstract}

Keywords: director-teacher; theater; model of creative personality 